\title{
Anatomy of the sphenopalatine artery and its implications for transnasal neurosurgery*
}

\author{
Márton Eördögh', András Grimm², Islam Gawish', Lajos Patonay², Robert \\ Reisch³, Hans Rudolf Briner ${ }^{4, \#}$, Gábor Baksa2,\#
}

Rhinology 56: 82-88, 2018

https://doi.org/10.4193/Rhino17.181

*Received for publication:

August 10, 2017

Accepted: October 14, 2017

\# contributed equally

Background: The knowledge of sinonasal vasculature is inevitable in transnasal neurosurgery. We performed an anatomical study on the sphenopalatine artery from the perspective of skull base procedures.

Methodology: To analyse the anatomical landmarks of the sphenopalatine artery, arterial skull corrosion casts ( 26 head halves) underwent endoscopic transnasal phantom surgery. Furthermore, we performed microsurgical dissection on formaldehyde-fixated cadavers with arterial perfusion ( 14 head halves) as well as studied Cone Beam CT-scans of anonymised patients and cadavers (115 head sides).

Results: In our cadaveric material, the sphenopalatine foramen is located at the transition of the superior and middle nasal meatus (95.0\%) or in the superior nasal meatus (5.0\%). It is the main entry point of the branches of the sphenopalatine artery into the nasal cavity. In most cadaveric cases (25.0\%), at this level there are 2 branches superiorly and 1 vessel inferiorly to the ethmoid crest. An average of 2.4 vessels leave the sphenopalatine foramen superiorly to the ethmoid crest, $97.8 \%$ of them belong to the sphenopalatine artery's posterior septal branches. An average of 2.1 branches leave the sphenopalatine foramen inferiorly to the ethmoid crest; all of them belong to the posterior lateral nasal branches. There are no cases with a single artery at the plane of the sphenopalatine foramen. We describe a triangular bony structure bordering the sphenopalatine foramen anteriorly which is built up by the palatine and ethmoid bone as well as the maxilla. According to the radiographic studies, this triangular prominence is surrounded superiorly by a posterior ethmoid cell (57.4\%), the sphenoid sinus (41.7\%) or the orbit (0.9\%) with a varying contribution of the superior nasal meatus; inferolaterally by the maxillary sinus (98.3\%) or the pterygopalatine and infratemporal fossa (1.7\%) and inferomedially by the middle nasal meatus. The medial vertex of the bony triangle corresponds to the ethmoid crest of the palatine bone. In transnasal endoscopic surgery, the posterior lateral nasal branches of the sphenopalatine artery appear at the triangle's inferomedial edge, the posterior septal branches emerge at its superior edge.

Conclusions: The triangular bony structure is a landmark to find and differentiate the posterior lateral nasal and posterior septal branches of the sphenopalatine artery and to identify the sphenoid sinus.

Key words: transnasal endoscopy, transethmoid-paraseptal approach, skull base surgery, sphenopalatine artery, sinonasal anatomy

\section{Introduction}

Transnasal neurosurgery embraces approaches to the pituitary gland and the skull base. The paradigm that these procedures begin at the level of the sphenoid sinus is shifting as an enor- mous experience is gathered on the sinonasal physiology and its relation to the quality of life. The knowledge of the sinonasal vascular anatomy became inevitable both for ENTs and neurosurgeons to perform extended intranasal dissection for 
skull base procedures. The understanding of the course of the sphenopalatine artery - particularly at the level of the sphenopalatine foramen - is prerequisite to control any bleeding in a safe and effective manner. On the other hand, harvesting a nasoseptal flap for skull base reconstruction after neurosurgical approaches also presumes detailed knowledge of the vascularization ${ }^{(1)}$. There is a need for reliable anatomical landmarks to identify the branches of the sphenopalatine artery. In this multimodal anatomical study, the sphenopalatine artery was studied with a neurosurgical focus by dissecting cadavers and analysing CT-scans of anonymised patients and cadavers.

\section{Materials and methods}

\section{Anatomical investigations}

The anatomical investigations were performed in 2013-2016 at the Department of Anatomy, Histology and Embryology, Semmelweis University, Budapest. A variety of methods was used on 30 fresh cadaveric heads (Table 1) to analyse the branches of the sphenopalatine artery and their relationship to the sphenopalatine foramen. Epidemiological data of the individuals was not collected.

19 sections of anonymous fresh cadaver heads underwent arterial perfusion via the maxillary artery with red coloured corrosion material (Akepox, Akemi chemisch technische Spezialfabrik GmbH, Nuremberg, Germany; Acrifix 2R 0190, Evonik Performance Materials GmbH, Essen, Germany). After injecting the maxillary artery with red coloured resin followed by careful non-enzymatic maceration on $60^{\circ} \mathrm{C}$ for $1-3$ months, the skulls were dried resulting in vascular corrosion cast of the nasal cavity's arterial system. These specimens (34 sides) underwent endoscopic phantom surgery using the unilateral combined transethmoid-paraseptal approach ${ }^{(2)}$. Here we simulated all circumstances of a real surgery (positioning of the head and the instruments, draping, etc.). We used $4 \mathrm{~mm} 0^{\circ}, 30^{\circ}$ and $70^{\circ}$ Aesculap TREND Minop endoscopes (Aesculap AG, Tuttlingen, Germany), light cable and Olympus CLV-S20 cold light source (Olympus Corp., Tokyo, Japan). The photographs were taken with a Canon EOS 5D digital camera (Canon Inc., Tokyo, Japan) adapted with a Wolf RIWO endoscopic objective (Richard Wolf $\mathrm{GmbH}$, Knittlingen, Germany) to the endoscope.

Further anonymous fresh cadaver heads underwent uni- or bilateral arterial perfusion of the maxillary artery with bariumsulfate- (Micropaque CT, Guerbet GmbH, Sulzbach, Germany), red coloured domestic gelatine- or red coloured latex (Liquid Latex Clear, Kryolan GmbH, Berlin, Germany). From them, a total of 14 sections of formaldehyde-fixated, mediansagittally divided head halves were prepared. Here, the region of the sphenopalatine foramen has been dissected under the surgical microscope with endoscopic assistance.

The facial and ethmoidal arteries and their relationship to the sphenopalatine artery were no subject to this study.
Table 1. Techniques used in cadaveric cases.

\begin{tabular}{|c|c|c|c|c|}
\hline Anatomical technique & $\begin{array}{c}\text { Investiga- } \\
\text { tion }\end{array}$ & $\begin{array}{l}\text { Total } \\
\text { case } \\
\text { No. }\end{array}$ & $\begin{array}{l}\text { Total } \\
\text { side } \\
\text { No. }\end{array}$ & $\begin{array}{l}\text { Side No. } \\
\text { with } \\
\text { evaluable } \\
\text { perfusion }\end{array}$ \\
\hline $\begin{array}{l}\text { Macerated skull, } \\
\text { arterial corrosion cast } \\
\text { (through MA) }\end{array}$ & $\begin{array}{l}\text { Endoscopic } \\
\text { transnasal } \\
\text { phantom } \\
\text { surgery }\end{array}$ & 19 & 34 & 26 \\
\hline $\begin{array}{l}\text { Formaldehyde fixated } \\
\text { head, barium-sulfate } \\
\text { perfusion through MA }\end{array}$ & \multirow{3}{*}{$\begin{array}{l}\text { Endoscope- } \\
\text { assisted } \\
\text { microsur- } \\
\text { gical dissec- } \\
\text { tion }\end{array}$} & 6 & 9 & 9 \\
\hline $\begin{array}{l}\text { Formaldehyde fixated } \\
\text { head, red gelatine per- } \\
\text { fusion through MA }\end{array}$ & & 4 & 4 & 4 \\
\hline $\begin{array}{l}\text { Formaldehyde fixated } \\
\text { head, red latex perfu- } \\
\text { sion through MA }\end{array}$ & & 1 & 1 & 1 \\
\hline Total & & 30 & 48 & 40 \\
\hline
\end{tabular}

$\mathrm{MA}=$ maxillary artery

\section{Radiological investigations}

Non-enhanced Cone Beam CT-scans of 49 randomised anonymised patients ( 25 females and 24 males, mean age: 50.5 years, range: 19-84 years) performed for non-tumourous dental surgical diagnostics were analysed to study the bony landmarks of the sphenopalatine foramen using the OsiriX application (Pixmeo SARL, Bernex, Switzerland). Furthermore, Cone Beam CT-scans of 9 cadaveric heads and halved heads (17 sides) including corrosion casts have also been investigated radiologically. The vascular anatomy was not studied on the radiological data. A total of 115 head sides have been analysed.

\section{Results}

In case of 19 corrosion casts (34 sides), a phantom surgery was performed. After uncinectomy and anterior ethmoidectomy, the basal lamella of the middle turbinate is visualised. Superiorly, the basal lamella attaches to the skull base. It spans laterally from the orbital lamina of the ethmoid bone to the middle turbinate medially. Here, its plane is more or less frontal. Posteroinferiorly, it flattens to horizontal and overgoes into the ethmoid crest on the lateral wall of the nasal cavity. The inferior continuation of the ethmoid crest - i.e. the lateral wall of the nasal cavity - is in the sagittal plane. From a frontal view, this transition of the upper frontal layer into a lower sagittal plane appears as a triangular prominence (Figure 1/I-III). It is built up by the orbital process and/or the perpendicular plate of the palatine bone, the ethmoid bone (including the ethmoid crest) and the maxilla. After the dissection of the frontal part of the basal lamella, the posterior ethmoid cells and/or the sphenoid sinus and the superior nasal meatus are exposed. The medial wall of the maxillary 


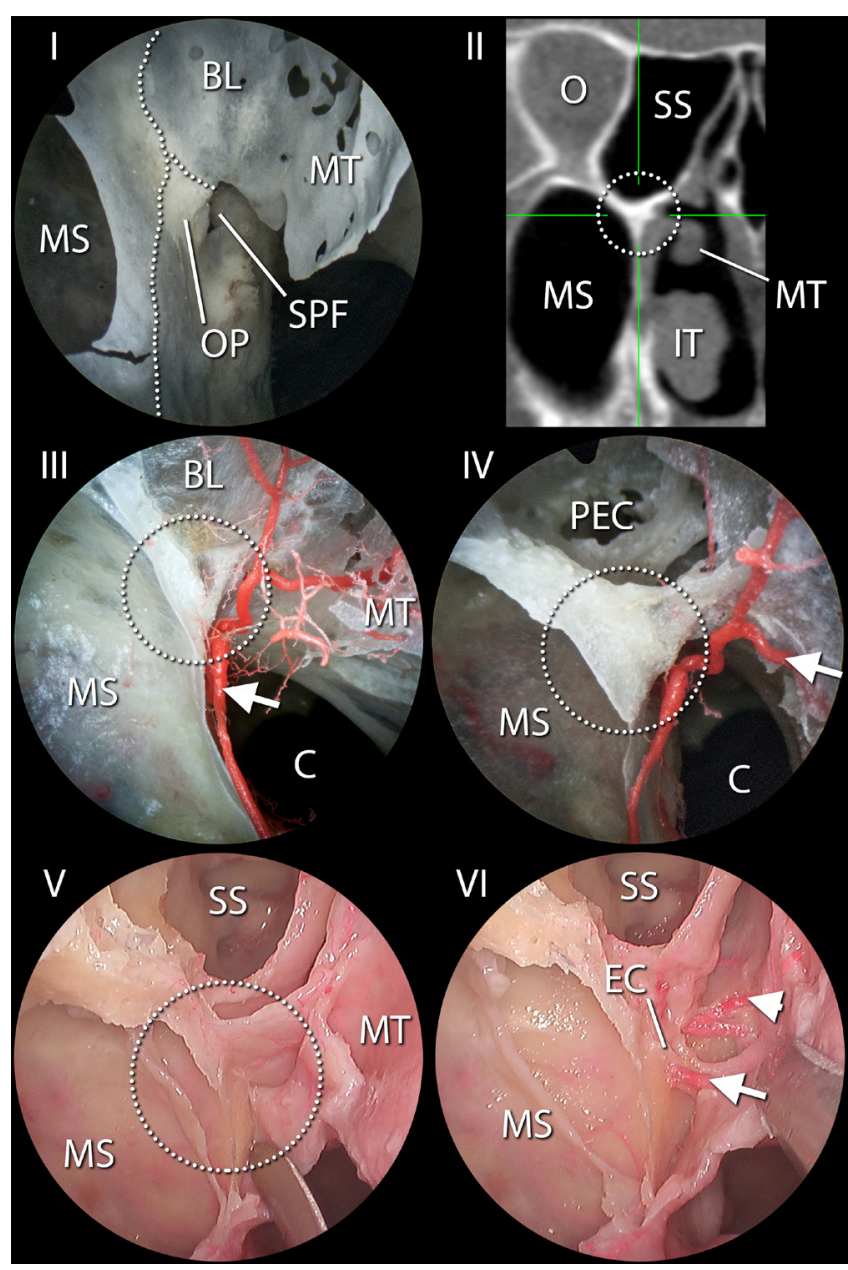

Figure 1. Endoscopic and radiological anatomy of the triangular prominence, right side.

I: Anteromedial view of the sphenopalatine foramen on an intact macerated skull. Note the borders (dotted lines) of the maxilla, the ethmoid and the palatine bone. II: Frontal CT-reconstruction of the triangular prominence (circle). It is bordered by the sphenoid sinus superiorly, the maxillary sinus inferolaterally and the middle nasal meatus inferomedially. The ethmoid crest appears as a medial bony notch. III: Frontal view of the triangular prominence (circle) and its relation to the posterior lateral nasal branches on an intact corrosion cast. IV: Frontal view of the triangular prominence (circle) on a corrosion cast after dissection of the posterior ethmoid cells. V: Frontal view of the triangular prominence (circle) on a fresh cadaver. VI: Dissection of the triangular prominence reveals the branches of the sphenopalatine artery.

$\mathrm{BL}=$ basal lamella of the middle turbinate; $\mathrm{C}=$ choana; $\mathrm{EC}=$ ethmoid crest; $I T$ = inferior turbinate; $M S$ = maxillary sinus; $M T=$ middle turbinate; $\mathrm{O}=$ orbit $; \mathrm{OP}=$ orbital process of the palatine bone; $\mathrm{PEC}=$ posterior ethmoid cell; SPF = sphenopalatine foramen; SS = sphenoid sinus; arrowhead = posterior septal branch(es) of the sphenopalatine artery; arrow = posterior lateral nasal branch(es) of the sphenopalatine artery.

sinus is dissected until its posterior wall is reached.

As a result of the ethmoidectomy and maxillary antrostomy, the triangular prominence can be better identified (Figure 1/IV-VI): the superior edge of the triangular prominence is a cut line of the frontal part of the basal lamella (and/or the middle turbinate itself). According to the radiological investigations on 115 head sides, it is superiorly bordered by a posterior ethmoid cell (66 sides, $57.4 \%$ ) or the anterior recess of the sphenoid sinus (48 sides, $41.7 \%)$, with a varying contribution of the superior nasal meatus (Figure 2 ). On one side (0.9\%) with maxillary sinus hypoplasia, it was superiorly bordered by the orbit. The inferomedial edge of the triangle is bordered by the middle nasal meatus. Its inferolateral edge is mostly (113 sides, $98.3 \%$ ) bordered by the maxillary sinus with the exception of one individual on both sides, where due to maxillary sinus hypoplasia it was bordered by the pterygopalatine and the infratemporal fossa (1.7\%). The inferior vertex of the triangular prominence is in continuation with the lateral wall of the nasal cavity. The medial vertex corresponds to the ethmoid crest of the palatine bone. The lateral vertex is in continuation with the attachment of the maxillary sinus and the ethmoid cells as well as/or the sphenoid sinus. The triangular prominence could have been identified in all cadaveric cases. It borders the sphenopalatine foramen anteriorly. This opening is the main entry point for arteries of the posterior two thirds of the nasal cavity. In case of 38 cadaveric head sides (95.0\%) from a total of 40 with evaluable perfusion, it is located at the transition of the superior and middle nasal meatus, crossed by the ethmoid crest; on further 2 sides (5.0\%) in the superior nasal meatus, superiorly to the ethmoid crest. In endoscopic surgery, the sphenopalatine artery's posterior septal branches appear at the superior edge of the triangular prominence (Figure 3). An average of 2.4 vessels (range: $1-6$ ) leave the sphenopalatine foramen superiorly to the ethmoid crest (i.e. to the attachment of the middle turbinate), most of them ( $97.8 \%$ of investigated vessels; $95.0 \%$ of cadaveric sides) belong to the posterior septal branches. The resection of the triangular prominence provides a better view of these vessels.

An average of 2.1 branches (range: $0-5$ ) leave the sphenopalatine foramen inferiorly to the ethmoid crest. In our material, all of them belong to the posterior lateral nasal branches and they emerge at the bony triangle's inferomedial edge. In case of 2 cadavers (5.0\% of cadaveric sides), the sphenopalatine foramen is located superiorly to the ethmoid crest (in the superior nasal meatus) meaning that the posterior lateral nasal branch appears superiorly to the ethmoid crest and courses to the inferomedial edge of the bony prominence.

Generally, at the plane of the sphenopalatine foramen, 8 cadaveric head sides (20.0\%) have 2 arterial branches, 14 sides (35.0\%) have 3 branches, 2 sides (5.0\%) have 4 branches, 6 sides (15.0\%) have 5 branches, 2 sides (5.0\%) have 6 branches, 2 sides (5.0\%) have 7 branches, 2 sides (5.0\%) have 8 branches, 3 sides (7.5\%) have 9 branches and 1 specimen (2.5\%) has 11 branches (Table 2). There aren't any sections with a single arterial trunk at 

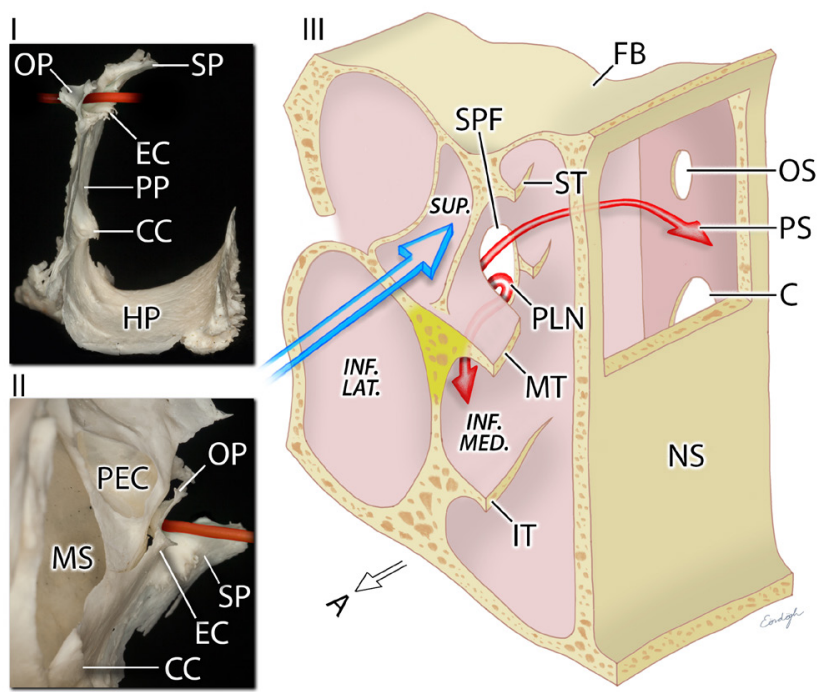

Figure 2. Macroscopic anatomy of the triangular prominence, right side. I: Frontal view of the palatine bone. Note the red wire crossing the sphenopalatine notch. II: Frontal view of the maxilla attached to the palatine bone, demonstrating the region of the triangular prominence. Note the red wire crossing the sphenopalatine notch. III: Schematic view of the nasal cavity's frontal cross-section at the plane of the triangular prominence. Superomedial aspect, $\mathrm{A}=$ anterior. The transethmoidal approach (blue arrow) traverses along the superior border of the triangular prominence (yellow). The red arrows mark the branches of the sphenopalatine artery and their relation to the middle turbinate/ethmoid crest. $\mathrm{C}=$ choana; $\mathrm{CC}=$ conchal crest (the attachment of the inferior turbinate); $E C=$ ethmoid crest; $F B=$ frontobasis; $\mathrm{HP}=$ horizontal plate of the palatine bone; IT = inferior turbinate; $M S=$ maxillary sinus; $M T=$ middle turbinate; NS = nasal septum; OP = orbital process of the palatine bone; OS = opening of the sphenoid sinus; PEC = posterior ethmoid cell; PLN $=$ posterior lateral nasal branches of the sphenopalatine artery; $\mathrm{PP}=$ perpendicular plate of the palatine bone; $P S=$ posterior septal branches of the sphenopalatine artery; SP = sphenoidal process of the palatine bone; SPF = sphenopalatine foramen; ST = superior turbinate.

\begin{tabular}{|c|c|c|}
\hline $\begin{array}{l}\text { Border of the } \\
\text { triangular } \\
\text { prominence }\end{array}$ & $\begin{array}{l}\text { Bordering anatomical } \\
\text { structure }\end{array}$ & Vascular relations \\
\hline $\begin{array}{l}\text { Superior } \\
\text { ("SUP.") }\end{array}$ & $\begin{array}{l}\text { Superior nasal meatus } \\
\text { and posterior ethmoid } \\
\text { cell }(57.4 \%) \text { or sphenoid } \\
\text { sinus }(41.7 \%) \text { or orbit } \\
(0.9 \%)\end{array}$ & $\begin{array}{l}\text { Posterior septal } \\
\text { branch(es) of the } \\
\text { sphenopalatine artery }\end{array}$ \\
\hline $\begin{array}{l}\text { Inferomedial } \\
\text { ("INF.MED.") }\end{array}$ & Middle nasal meatus & $\begin{array}{l}\text { Posterior lateral nasal } \\
\text { branch(es) of the } \\
\text { sphenopalatine artery }\end{array}$ \\
\hline $\begin{array}{l}\text { Inferolateral } \\
\text { ("INF.LAT.") }\end{array}$ & $\begin{array}{l}\text { Maxillary sinus ( } 98.3 \%) \text { or } \\
\text { pterygopalatine and in- } \\
\text { fratemporal fossa }(1.7 \%)\end{array}$ & (None) \\
\hline
\end{tabular}

the level of the sphenopalatine foramen; $17.5 \%$ (7 sides) have 1 superior and 1 inferior branch. In most cases (10 cases, 25.0\%),

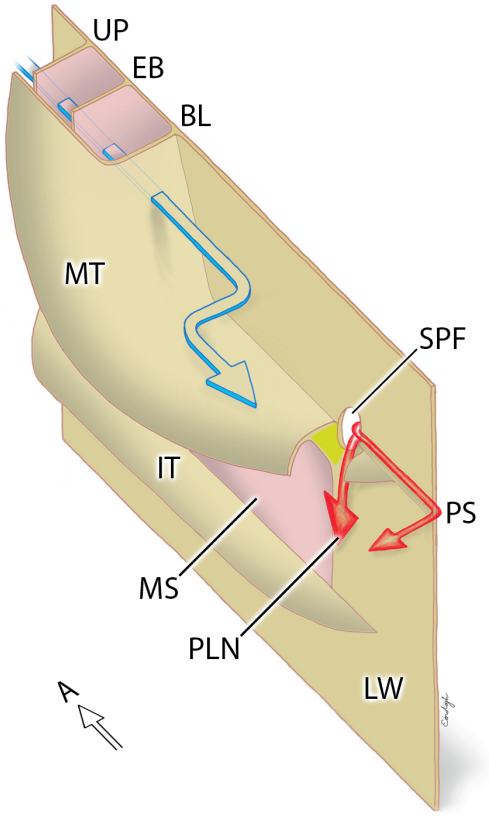

Figure 3. Schematic view of the nasal cavity and ethmoid cells, right side. Posterosuperior aspect, $A=$ anterior. Adaption of Stammberger's middle turbinate model ${ }^{(22)}$. The transethmoidal approach (blue arrow) traverses the uncinate process, the ethmoid bulla and the basal lamella of the middle turbinate. The red arrows mark the branches of the sphenopalatine artery: the posterior lateral nasal branches appear at the bony triangle's (yellow) inferomedial edge, the posterior septal branches emerge at the superior edge.

$\mathrm{BL}=$ basal lamella of the middle turbinate; $\mathrm{EB}=$ anterior wall of the ethmoid bulla; IT = inferior turbinate; LW = lateral wall of the nasal cavity; $M S=$ maxillary sinus; $M T=$ middle turbinate; $P L N=$ posterior lateral nasal branches of the sphenopalatine artery; PS = posterior septal branches of the sphenopalatine artery; SPF = sphenopalatine foramen; $\mathrm{UP}=$ uncinate process.

there are 2 superior branches and 1 inferior vessel. At the sagittal plane of the opening of the sphenoid sinus, an average of 2.6 branches (range: $1-5$ ) are identified. $0-3$ pieces of accessory foramina could also have been identified. On 8 sides we failed to find any arteries due to insufficient filling of the vessels.

\section{Discussion}

Initially, transnasal neurosurgery was considered to begin at the level of the sphenoid sinus, that is why neurosurgeons might devote less caution to sinonasal structures. Later, an enormous development took place resulting in a wide variety of treatable skull base pathologies ${ }^{(3)}$. Tailored intranasal dissection based on rhinological principles and the individual pathoanatomy may also improve results.

Knowledge of the vascular anatomy is a necessary to avoid intraoperative bleeding and to lower the risk of postoperative 
Table 2. Number of branches of the sphenopalatine artery in the plane of the sphenopalatine foramen in relation to the ethmoid crest $(\mathrm{N}=40$, results given in \%)

\begin{tabular}{|c|c|c|c|c|c|c|c|}
\hline \multirow{8}{*}{ 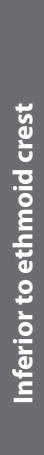 } & & \multicolumn{6}{|c|}{ Superior to ethmoid crest } \\
\hline & & 1 & 2 & 3 & 4 & 5 & 6 \\
\hline & 0 & & 2.5 & 2.5 & & & \\
\hline & 1 & 17.5 & 25.0 & 2.5 & & 2.5 & \\
\hline & 2 & 7.5 & 2.5 & 2.5 & 2.5 & & \\
\hline & 3 & & 10.0 & & & 2.5 & \\
\hline & 4 & 2.5 & & 2.5 & & 2.5 & \\
\hline & 5 & & 2.5 & 2.5 & 5.0 & & 2.5 \\
\hline
\end{tabular}

bleeding. Epistaxis is a well-known clinical condition with a notable morbidity ${ }^{(4)}$. Therapeutic methods including nasal packing, transantral (Caldwell-Luc) ligation, interventional embolisation may lead to facial pain, synechiae, sinusitis, periorbital cellulitis, toxic shock syndrome, otitis media, ophthalmic palsy and blindness ${ }^{(5-7)}$. However, endoscopic transnasal surgery with cauterization or ligation of the bleeding artery may avoid most of these complications ${ }^{(8)}$.

Intranasal surgical dissection relies on bony anatomical landmarks. Therefore, the sinonasal osteology was extensively investigated. In a study of Wareing and Padgham ${ }^{(9)}$, the most common localization of the sphenopalatine foramen was found at the transition of the middle and superior meatus. This has been verified by many workgroups ${ }^{(10-12)}$ and also matches to our findings (Table 3). However, in our material there weren't any cases with solely middle meatal localisation, which necessitates further analysis.

Initially suggested by Budrovich et al. ${ }^{(13)}$, the ethmoid crest was considered to be a constant landmark to find the sphenopalatine artery ${ }^{(10)}$. We rather agree with Pearson ${ }^{(14)}$, who considered the orbital process of the palatine bone as an important structure. Performing transantral approaches, he regularly removed it to visualise the posterior septal branches. To our experience, the orbital process of the palatine bone builds up the triangular bony prominence along with the maxilla and the ethmoid bone, serving as a useful landmark.

Most studies describe more than one artery at the plane of the sphenopalatine foramen which may possibly lead to the failure of epistaxis management, particularly if more posterior branches remain unseen during surgery ${ }^{(5,15)}$ (Table 4). Bolger ${ }^{(16)}$, Wareing and Padgham (9) as well as Midilli ${ }^{(11)}$ also noted that a posterior septal branch was situated more superiorly and posteriorly in comparison to the posterior lateral nasal branch, even if using a different nomenclature. Schwartzbauer et al. demonstrated three variations of two separate vessels emerging at the
Table 3. Localisation of the sphenopalatine foramen (\%).

\begin{tabular}{|c|c|c|c|c|}
\hline Study, year (material) & $\begin{array}{l}\text { Middle } \\
\text { and } \\
\text { supe- } \\
\text { rior } \\
\text { mea- } \\
\text { tus }\end{array}$ & $\begin{array}{l}\text { Supe- } \\
\text { rior } \\
\text { mea- } \\
\text { tus }\end{array}$ & $\begin{array}{c}\text { Middle } \\
\text { mea- } \\
\text { tus }\end{array}$ & $\begin{array}{c}\text { Su- } \\
\text { preme } \\
\text { mea- } \\
\text { tus }\end{array}$ \\
\hline $\begin{array}{l}\text { Wareing \& Padgham }{ }^{(25)}, 1998 \\
\text { (220 skull sides) }\end{array}$ & 65 & 35 & & \\
\hline $\begin{array}{l}\text { Lee et al. }{ }^{\left({ }^{8}\right)}, 2002 \\
\text { (50 cadaveric sides) }\end{array}$ & & 90 & & 10 \\
\hline $\begin{array}{l}\text { Pádua \& Voegels }{ }^{(14)}, 2008 \\
\text { (122 cadaveric sides) }\end{array}$ & 87 & 13 & & \\
\hline $\begin{array}{l}\text { Scanavine et al. }{ }^{(17)}, 2009 \text { (53 skull } \\
\text { sides; } 1 \text { side has been excluded) }\end{array}$ & 15 & 83 & 2 & \\
\hline $\begin{array}{l}\text { Tolosana et al. }{ }^{(7)}, 2011 \\
\text { (32 skull sides) }\end{array}$ & 56 & 38 & 6 & \\
\hline $\begin{array}{l}\text { Present study ( } 40 \text { cadaveric } \\
\text { sides with arterial perfusion) }\end{array}$ & 95 & 5 & & \\
\hline
\end{tabular}

region of the sphenopalatine foramen ${ }^{(17)}$.

Even Zuckerkandl ${ }^{(18)}$ distinguished the posterior nasal (lateral) and the nasopalatine artery (medial), pointing out, that they give each other branches, resulting in a rich arborization. The anatomy of the sphenopalatine artery on fresh cadavers with latex perfusion was extensively investigated by Simmen et al. (5). In $97 \%$ of their cases, more than one branch was seen at the plane of the sphenopalatine foramen. However, a correlation between the foraminal entry point and course of the arteries was not seen. In our material, the posterior lateral nasal branches appeared at the inferior edge of the triangular prominence, the posterior septal branches were seen at its superior border. However, a crossed configuration can be also possible ${ }^{(19)}$. We did not find any description about the sphenopalatine artery for neurosurgical approaches, even though epistaxis management is a popular topic in the rhinosurgical literature. Midilli et al. suggest a two-step-cauterization instead of extensive dissection of the sphenopalatine foramen ${ }^{(20)}$ : after ligation of the posterior lateral nasal branches, the middle turbinate is lateralised and an incision 2-3 mm posterior to the posterior border of the middle turbinate is performed. The septal branches can be distally visualised by elevating the mucosa on the anterior wall of the sphenoid. Using the bony triangle as a landmark offers a proximal control, as it frames the sphenopalatine foramen anteriorly.

The individual arrangement of the vasculature is unpredictable. We found 1-5 arteries at the plane of the opening of the sphenoid sinus on its anterior wall. Each may serve as a bleeding source. A proximal foraminal control is advocated, respectively. The key point of any surgery should be the identification of each sphenopalatine arterial branch at the foraminal level to prevent any vascular complications or to harvest a pedicled (rescue) flap. 
Table 4. Number of sphenopalatine artery branches at the plane of the sphenopalatine foramen (\%).

\begin{tabular}{|c|c|c|c|c|c|c|c|c|c|c|c|}
\hline Study, year (material) & 1 & 2 & 3 & 4 & 5 & 6 & 7 & 8 & 9 & 10 & 11 \\
\hline Ram et al. ${ }^{(16)}, 2000$ (surgical procedures on 6 sides) & 83 & 17 & & & & & & & & & \\
\hline Lee et al. ${ }^{(8)}, 2002$ (50 cadaveric sides) & & 76 & 22 & 2 & & & & & & & \\
\hline Babin et al. ${ }^{(2)}, 2003$ (20 cadaveric sides) & 10 & 50 & 30 & 5 & 5 & & & & & & \\
\hline Schwartzbauer et al. ${ }^{(20)}, 2003$ (19 cadaveric sides) & & 100 & & & & & & & & & \\
\hline Simmen et al. ${ }^{(24)}, 2006$ (75 cadaveric sides) & 3 & 32 & 31 & 16 & 12 & 1 & 4 & & & 1 & \\
\hline Pádua \& Voegels ${ }^{(14)}, 2008$ (122 cadaveric sides) & 67 & 21 & 12 & & & & & & & & \\
\hline $\begin{array}{l}\text { Gras-Cabrerizo }{ }^{(5)}, 2013 \text { (surgical procedures on } 17 \text { sides, } 90 \text { cadaveric } \\
\text { sides) }\end{array}$ & 63 & 32 & 5 & & & & & & & & \\
\hline Present study (40 cadaveric sides) & & 20.0 & 35.0 & 5.0 & 15.0 & 5.0 & 5.0 & 5.0 & 7.5 & & 2.5 \\
\hline
\end{tabular}

The endoscopic unilateral transethmoidal-paraseptal approach is the standard transnasal neurosurgical technique of the senior authors (RR, HRB). The elective dissection of the branches of the sphenopalatine artery - implemented into this technique could have been achieved with the identification of the bony triangle which seemed to be a constant, even on CT-scans recognisable anatomical landmark for all foraminal sphenopalatine branches. Furthermore, its superior border marks the pathway to the sphenoid sinus and is adjacent in $41.7 \%$ to it. Failures such as accidental dissection of the ethmoid fovea with consecutive CSF-leak can be avoided. Addressing the nasal vasculature in this gentle and effective manner can prevent excessive cautery that may impair sinonasal function. The senior authors reported on a $100 \%$ occurrence of the bony prominence based on data of 53 performed surgeries.

In very seldom cases, the triangular bony prominence may not be used as a landmark: The prevalence of maxillary sinus hypoplasia seen on one CT-scan might hinder the antrostomy and the bony prominence can remain undeveloped. However, this can be predicted by studying scans prior surgery ${ }^{(21)}$. Furthermore, as the visualisation of the bony triangle is a result of the described transethmoid-paraseptal dissection, it is limited available for different neurosurgical techniques.

In this study, an anatomical cohort derived from different preparation techniques was analysed. For each aspect of this work we set different goals that is why we used various methods. To investigate the bony relations and landmarks for arteries, we preferred arterial corrosion cast skulls. In comparison to the formaldehyde-fixed or fresh cadavers with gelatine-, barium- or polyurethane-perfusion, corrosion cast skulls might offer a more accurate investigation of the vasculature with filling of the small vessels as well. Nevertheless, each technique seemed to be suitable. To our knowledge, this is the first study in this topic applying corrosion cast material.

\section{Conclusion}

The presence of at least two arterial branches at the plane of the sphenopalatine foramen is a common finding. The individual arrangement of the arterial branches is unpredictable. The bony triangle described above is an important landmark to differentiate the posterior lateral nasal and posterior septal branches of the sphenopalatine artery and to identify the sphenoid sinus. Comparison of clinical and anatomical data is necessary.

\section{Acknowledgements}

This research received no specific grant from any funding agency in the public, commercial, or not-for-profit sectors.

\section{Authorship contribution}

Conception and design of the work: ME, AG, IG, LP, RR, HRB, GB; Data collection: ME, AG, RR, HRB, GB, LP; Data analysis and interpretation: $M E, R R, H R B, G B, I G$; Drafting the article: $M E, H R B$, $G B, R R, L P$; Critical revision of the article: $M E, A G, I G, L P, R R, H R B$, $G B$; Final approval of the version to be published: $M E, A G, I G, L P$, RR, HRB, GB.

\section{Conflict of interest}

None

\section{References}

1. Hadad G, Bassagasteguy L, Carrau RL, Mataza JC, Kassam A, Snyderman CH, et al. A novel reconstructive technique after endoscopic expanded endonasal approaches: vascular pedicle nasoseptal flap. Laryngoscope. 2006 Oct;116(10):18826.

2. Eördögh $M$, Briner HR, Simmen $D$, Jones $\mathrm{N}$, Reisch R. Endoscopic unilateral trans ethmoid-paraseptal approach to the central skull base. Laryngoscope Investigative
Otolaryngology. 2017;102(1):198.

3. Schwartz T, Fraser J, Brown S, Tabaee A. Endoscopic cranial base surgery: classification of operative approaches. Neurosurgery. 2008 Jan 1;62:991-1005

4. Ram B, White PS, Saleh HA, Odutoye T, 
Cain A. Endoscopic endonasal ligation of the sphenopalatine artery. Rhinology. 2000;38:147-9.

5. Simmen DB, Raghavan U, Briner HR. The anatomy of the sphenopalatine artery for the endoscopic sinus surgeon. Am J Rhinol. 2006;20:502-5.

6. Schaitkin B, Strauss M, Houck JR. Epistaxis: medical versus surgical therapy: a com parison of efficacy, complications, and economic considerations. Laryngoscope. 1987 Dec;97(12):1392-6.

7. O'Leary-Stickney K, Makielski K, Weymuller EA. Rigid endoscopy for the control of epistaxis. Arch Otolaryngol Head Neck Surg. 1992 Sep;118(9):966-7.

8. White PS. Endoscopic ligation of the sphenopalatine artery (ELSA): a preliminary description. J Laryngol Otol. 1996 Jan;110(1):27-30.

9. Wareing MJ, Padgham ND. Osteologic classification of the sphenopalatine foramen. Laryngoscope. 1998 Jan;108(1 Pt 1):125-7.

10. Pádua FGM, Voegels RL. Severe posterior epistaxis-endoscopic surgical anatomy Laryngoscope. 2008 Jan;118(1):156-61.

11. Midilli R, Aladağ G, Erginöz E, Karci B, Savaş R. Anatomic variations of the paranasal sinuses detected by computed tomography and the relationship between variations and sex. Kulak Burun Bogaz Ihtis Derg. 2005;14(3-4):49-56.
12. Herrera Tolosana S, Fernández Liesa R, Escolar Castellón J de D, Pérez Delgado L, Lisbona Alquezar MP, Tejero-Garcés Galve G, et al. Sphenopalatinum foramen: an anatomical study. Acta Otorrinolaringol Esp. 2011 Jul;62(4):274-8.

13. Budrovich R, Saetti R. Microscopic and endoscopic ligature of the sphenopalatine artery. Laryngoscope. 1992 Dec;102(12 Pt 1):1391-4.

14. Pearson BW, Mackenzie RG, Goodman WS The anatomical basis of transantral ligation of the maxillary artery in severe epistaxis. Laryngoscope. 1969;79(5):969-84.

15. Babin E, Moreau S, de Rugy MG, Delmas P, Valdazo A, Bequignon A. Anatomic variations of the arteries of the nasal fossa. Otolaryngol Head Neck Surg. 2003 Feb;128(2):236-9.

16. Bolger WE, Borgie RC, Melder P. The role of the crista ethmoidalis in endoscopic sphenopalatine artery ligation. Am J Rhinol. 1999 Mar;13(2):81-6.

17. Schwartzbauer HR, Shete M, Tami TA. Endoscopic anatomy of the sphenopalatine and posterior nasal arteries: implications for the endoscopic management of epistaxis. Am J Rhinol. 2003 Jan;17(1):63-6.

18. Zuckerkandl E. Normale und pathologische Anatomie der Nasenhöhle und ihrer pneumatischen Anhänge. Wien, Leipzig: W. Braumüller; 1893.
19. Lee HY, Kim H-U, Kim S-S, Son EJ, Kim JW, Cho $\mathrm{NH}$, et al. Surgical anatomy of the sphenopalatine artery in lateral nasal wall. Laryngoscope. 2002 Oct;112(10):1813-8.

20. Midilli R, Orhan M, Saylam CY, Akyildiz S, Gode S, Karci B. Anatomic variations of sphenopalatine artery and minimally invasive surgical cauterization procedure. Am J Rhinol Allergy. 2009 Nov 1;23(6):38-41.

21. Sirikçi A. A new approach to the classification of maxillary sinus hypoplasia with relevant clinical implications. Surg Radiol Anat. 2000;22:234-47.

22. Stammberger H. F.E.S.S. - Endoscopic Diagnosis and Surgery of the Paranasal Sinuses and Anterior Skull Base. Tuttlingen: Endo-Press; 2006.

\section{Márton Eördögh MD \\ Neurochirurgische Klinik \\ KRH Klinikum Nordstadt \\ Haltenhoffstr. 41 \\ 30167 Hannover}

Germany

E-mail: marton.eordogh@gmail.com 